\title{
Hatay İlinde Tüketicilerin Süt ve Süt Ürünleri Satın Alma Davranışları ve Tüketici Tercihlerini Etkileyen Faktörler: İskenderun İlçesi Örneği
}

\author{
Nuran TAPKI*, İbrahim TAPKI, Erdal DAĞISTAN, Kübra SAPMAZ
}

Hatay Mustafa Kemal Üniversitesi, Ziraat Fakültesi, Tarım Ekonomisi Bölümü, Hatay, Türkiye

Nuran TAPKI, ORCID No: 0000-0001-5044-795X, İbrahim TAPKI, ORCID No: 0000-0002-4552-6941, Erdal DAĞISTAN, ORCID No: 0000-0003-0987-9034, Kübra SAPMAZ, ORCID No: 0000-0002-1304-6943

\begin{tabular}{|c|c|}
\hline MAKALE B İLGİSİ & ÖZET \\
\hline Araştırma Makalesi & \multirow{12}{*}{$\begin{array}{l}\text { Bu çalışmanın amacı, Hatay İli İskenderun ilçesindeki tüketicilerin süt } \\
\text { ve süt ürünleri satın alma davranışlarını ve tüketici tercihlerini etkileyen } \\
\text { faktörleri belirlemektir. Araştırmada } 2020 \text { yılında İskenderun ilçesinde } \\
\text { tüketicilerle yapılan anketler çalışmanın ana materyalini oluşturmuştur. } \\
\text { Çalışmada, tüketicilerin cinsiyet, yaş, eğitim ve aylık gelir düzeyi ile süt } \\
\text { ve süt ürünleri satın alma tercihleri ortaya konmuştur. Verilerin } \\
\text { analizinde ki-kare istatistiki testi kullanılmıştır. Tüketicilerin \%o6'si } \\
\text { açık süt, \%12’si pastörize süt ve \%26’sı da paket (UHT) süt tercih } \\
\text { etmektedir. Tüketicilerde eğitim düzeyi arttıkça süt ve süt ürünlerini } \\
\text { market ve süpermarketlerden satın alma eğilimi artmaktadır. } \\
\text { Tüketicilerin süt ve süt ürünleri tercihinde, hijyen, sütün sağlıklı olmas, } \\
\text { sütün fiyatı, son tüketim tarihi ve doktor tavsiyeleri etkili olmuştur. } \\
\text { Tüketiciler süt ve süt ürünleri satın alırken, marka tercihinde kalitenin } \\
\text { çok etkili olduğu gözlenmiştir. Araştırma sonuçları, süt ve süt } \\
\text { ürünlerinin insan sağlığına olan katkısını artırmak için süt ve süt ürünleri } \\
\text { üretiminde tüketici tercihlerinin dikkate alınması ve buna uygun } \\
\text { politikaların geliştirilmesinin yararlı olacağını ortaya koymuştur. }\end{array}$} \\
\hline Geliş : 12.02 .2021 & \\
\hline Kabul : 06.04.2021 & \\
\hline Anahtar Kelimeler & \\
\hline Hatay & \\
\hline Kalite & \\
\hline $\begin{array}{l}\text { Sosyo-ekonomi } \\
\text { Marka }\end{array}$ & \\
\hline * Sorumlu Yazar & \\
\hline ntapki@mku.edu.tr & \\
\hline & \\
\hline & \\
\hline & \\
\hline
\end{tabular}

\section{Consumers' Milk and Milk Products Purchasing Behaviors and the Factors Affecting Consumer Preferences in Hatay Province : The Case of İskenderun District}

\begin{tabular}{|c|c|}
\hline ARTICLE INFO & ABSTRACT \\
\hline Research Article & \multirow{8}{*}{$\begin{array}{l}\text { The aim of this study is to determine the factors affecting the milk and } \\
\text { milk product purchasing behavior and consumer preferences of the } \\
\text { consumers in Iskenderun district of Hatay Province. In this research, } \\
\text { study conducted with consumers in İskenderun district in } 2020 \\
\text { constituted the main material of the study. In the study, the gender, age, } \\
\text { education and monthly income level of the consumers and their } \\
\text { preferences to purchase milk and dairy products were revealed. Chi- } \\
\text { square statistical test was used to analyze the data. Sixty two percent of } \\
\text { the consumers prefer open milk, 12\% pasteurized milk and 26\% } \\
\text { packaged (UHT) milk. As the education level of consumers increases, }\end{array}$} \\
\hline Received : 12.02.2021 & \\
\hline Accepted : 06.04.2021 & \\
\hline Keywords & \\
\hline Hatay & \\
\hline Quality & \\
\hline Socio-economy & \\
\hline Brand & \\
\hline
\end{tabular}

Lütfen aşağıdaki şekilde atıf yapınız / Please cite this paper as following;

Tapkı, N., Tapkı, İ., Dağıstan, E., Sapmaz, K., 2021. Hatay İlinde tüketicilerin süt ve süt ürünleri tüketim yerleri ve tüketici tercihlerini etkileyen faktörler: İskenderun İlçesi örneği, Journal of Animal Science and Products (JASP) 4 (1):10-22. 


\section{* Corresponding Author}

ntapki@mku.edu.tr the tendency to purchase milk and dairy products from markets and supermarkets increases. The hygiene, the healthiness and price of the milk, the expiry date, and the doctor's recommendations were effective in consumers' preferences for milk and dairy products. While consumers are purchasing milk and dairy products, it has been observed that quality is very effective in brand preference. The results revealed that it would be beneficial to take into account consumer preferences in milk and milk products production and to develop appropriate policies in order to increase the contribution of milk and milk products to human health.

\section{Giriş}

İnsan hayatında süt ve süt ürünleri çok önemli bir yere sahiptir. $\mathrm{Bu}$ nedenle, gelecek nesillerin daha sağlıklı olabilmeleri, tüketicilerin gıda güvenliği ve kaliteli g1da tüketimi bakımından daha bilinçli olmalarına bağlıdır (Gündüz ve ark., 2013).

Günümüzde hizmet sektöründe faaliyet gösteren firmalar tüketici tercihlerine göre hareket etmek durumundadır. $\mathrm{Bu}$ nedenle firmalar tüketici beklentilerini dikkate alan ve tüketicilerin üzerinde durduğu kriterleri belirleyen araştırmalar yaptırmalı ve elde edilen sonuçlardan da yoğun bir şekilde yararlanmalıdır (Gündüz ve ark., 2013).

Türkiye'de süt ve süt ürünleri üretimi, toplam hayvansal üretim değerinin \%41,2'sini, toplam pazarlanan değerin ise \%31,5'ini oluşturmaktadır. Türkiye'de ortalama kişi başına y1llık süt tüketimi 146 litre olup, bu tüketimin 23 litresini içme sütü ve kalanını ise süt ürünleri oluşturmaktadır. ABD'de ise bu miktar ortalama 292 litre ve AB ülkelerinde ise 342,5 litredir (Küçük, 2020).

Türkiye'de süt ve süt ürünleri tüketimi konusunda yapılmış olan birçok çalışma bulunmaktadır. Ancak, bu çalışmaların tüketici tercihlerinin belirlenmesi bakımından sık sık yenilenmesi gerekmektedir. Araştırmaların iller bazında yapılması, tüketicilerin bilinç düzeyinin gelişmesine ve değişmesine katkı sağlayacaktır (Erdal ve Tokgöz, 2011).

Çelik ve ark. (2005), Şanlıurfa'da, aile başına aylık süt tüketimini ortalama 16,4 litre, aylık süt harcamasının toplam gıda harcaması içindeki payını \%5,3 olarak hesaplamışlardır. Ailelerin tükettikleri sütün \%46,3'ünü açık sütler ve \%53,7'sini ise ambalajlı sütler oluşturmuştur.

Gündüz ve ark. (2013), Samsun ilinde süt ve süt ürünleri tüketimi bakımından tüketici tercihlerini etkileyen faktörleri araştırdıkları çalışmada, hanelerde ortalama geliri 1.951 TL olarak belirlemişlerdir. Yine çalışmada, hijyen, sütün sağlıklı olması, son kullanım tarihi, sağlık sorunları, doktor tavsiyesi ve fiyat gibi faktörlerin tüketici tercihlerinde önemli etkiye sahip oldukları ifade edilmiştir.

Niyaz ve İnan (2016) çalışmalarında, her gün düzenli olarak süt tüketenlerin oranının $\% 16,0$ ve tüketilen sütün büyük bir kısmının da inek sütü olduğunu belirlemişlerdir.

Erzincan ilinde yürütülen bir çalışmada, tüketicilerin süt, peynir ve yoğurt tüketiminde daha çok inek sütünü tercih ettikleri, satın alınan çiğ sütün \%69,9'unun sokak sütçüleri ya da üreticilerden, \%30,1'inin ise pastörize ve UHT sütlerden oluştuğunu belirtilmiştir (Çebi ve ark., 2018).

Özyürek ve ark. (2019), Erzincan Üniversitesi öğrencileri üzerinde yürüttükleri bir çalışmalarında, öğrencilerin \%77,4’ünün ambalajlı sütlerin katkı maddesi içerdiğine inandıklarını ve \%71,1'inin ise süt satın alırken içerdiği yăg miktarına baktıklarını, 
öğrencilerin ürün alımında firmaya önem verdiklerini ve peynir alımında ise daha çok beyaz peyniri tercih ettikleri belirlenmiştir.

Burdur ilinde 65 yaş ve üzeri tüketiciler üzerinde yürütülen bir çalışmada, tüketicilerin süt ve süt ürünleri tüketim alışkanlıkları belirlenmeye çalışılmıştır. Gelir düzeyi düşük olan yaşlıların pastörize ve UHT süt tüketimleri ile süt ve süt ürünlerine yaptıkları harcamanın düşük olduğu ifade edilmiştir (Say Şahin ve Saraç, 2019).

Kibar ve ark.(2020), Siirt ilinde yürüttükleri çalışmalarında, tüketicilerin büyük bir kısmının süt fiyatlarını yüksek ve çok az bir kısmının ise orta düzeyde bulduklarını, çoğunlukla koyun ve keçi sütü tüketiminden yana olduklarını, bunun sebebinin ise yörede küçükbaş hayvancılık faaliyetinin yaygın olmasından kaynakladığını ortaya koymuşlardır.

$\mathrm{Bu}$ çalışmada, süt ve süt ürünleri tüketimi açısından Hatay ili İskenderun ilçesindeki tüketicilerin süt ve süt ürünleri bakımından tüketim bilinçleri, süt ve süt ürünleri satın alma davranışları, yaş, sosyo-ekonomik özellikleri, süt ve süt ürünü satın aldıkları yerler, tüketici tercihlerini belirleyen faktörler ile tüketicilerin karar alırken hangi faktörleri dikkate aldıkları belirlenmeye çalışılmıştır.

\section{Materyal ve Yöntem}

\section{Materyal}

Araştırmanın ana materyalini Hatay ili İskenderun ilçesi şehir merkezinde yaşayan 18 yaş ve üzerindeki tüketicilerden anket yöntemi ile elde edilen birincil veriler oluşturmuştur. Çalışmanın etik kurul onay belge tarih ve sayısı: 12/10/2020-E.47155.

\section{Yöntem}

Çalışmada tüketiciler gönüllü katılım ile market, alışveriş merkezi ve sokaktaki bireylerden seçilmiştir. Örnek büyüklüğü "Ana kitle Oranlarına Dayalı Kümelendirilmemiş Tesadüfi Olasılık Örnekleme" yöntemi ile belirlenmiştir (Collins, 1986; Karakaya ve Akbay, 2014).

$\mathrm{n}=\mathrm{t}^{2} *[1+(0.02)(\mathrm{b}-1)] *(\mathrm{p} * \mathrm{q}) / \mathrm{e}^{2}$

n: Örnek sayısı, t: 1,96 (\%95 önem derecesine karşılık gelen $\mathrm{z}$ tablo değeri),p: incelenen olayın ana kitle içerisinde gerçekleşme olasılığ 1 (\%50 olarak alınmıştır),q: (1-p) İncelenen olayın gerçekleşmeme durumu, e:Kabul edilen hata payı (Çalışmada hata payı \%5 olarak alınmıştır)

Denklemde $b=1$ alındığında, eşitlik şu şekildedir.

$\mathrm{n}=\mathrm{t}^{2 *}\left(\mathrm{p}^{*} \mathrm{q}\right) / \mathrm{e}^{2}$

Formule göre örnek büyüklügüü,

$\mathrm{n}=1,96^{2 *}(0,50 * 0,50) / 0,05^{2}$

$\mathrm{n}=384$ (Örnek hacmi 384’tür).

Araştırmada tüketicilerin demografik özellikleri ve satın alma davranışlarını ortaya koyan veriler çapraz tablolar, yüzdeler ve ki-kare hesaplamaları yapılarak verilmiştir. Ki-kare testi frekans dağılımları üzerinden analiz yaptığından, değişkenler arasındaki ilişkiler ve farklılıklar ki-kare analizi ile ortaya konulmuştur. Bu test, ki-kare uygunluk ve bağımsızlık testi olarak iki şekilde yapılmaktadır (Altunışık ve ark., 2005; Sevimli ve Gülçubuk, 2018; 
Tapk1 ve ark., 2020). Bu çalışmada incelenen konular arasındaki farklılıklar, ki-kare testi ile analiz edilmiştir.

Araştırmada ayrıca, Likert Ölçeğinden yararlanılmıştır. Likert Ölçeği, özellikle pazarlama araştırmalarında tüketici tutumlarının ortaya konulmasında önemli ölçüde kullanılan bir yöntem olup, araştırmaya katılanların araştırmada kullanılan ifadeleri ne ölçüde benimsediklerini ortaya koymaktadır (Malhotra, 2004; Gündüz ve ark., 2013). Tüketicilere yöneltilen anket sorularının güvenilirliğini ortaya koymak için Güvenilirlik Analizi yapıımış, Cronbach's alpha katsayıları belirlenmiştir (Erman, 2007).

\section{Bulgular ve Tartışma}

Araştırma kapsamındaki tüketicilerin \%40,1'i erkek ve \%59,9'u kadınlardan oluşmaktadır. Tüketicilerin yaş ortalaması 39,3 tür. 18-30 yaş arasındaki tüketicilerin oranı $\% 24,6$ ve 61 yaş ve üzeri ise \%1,8 olarak gerçekleşmiştir. Görüşülen tüketicilerin \%57,0'lik bölümünü 3-4 kişilik aileler oluşturmakta olup, 4 ve daha fazla aile bireyine sahip ailelerin oranı ise \%26,0 olarak belirlenmiştir. Ortalama aile büyüklüğü 3,7 kişi olarak hesaplanmıştır. Gündüz ve ark, (2013) Samsun ilinde yaptıkları çalışmada, ailelerin ortalama büyüklüğünü 3.4 kişi, Çelik ve ark, (2005) ise Şanlıurfa ilinde yaptıkları çalışmada 5,4 kişi olarak tespit etmiştir. Araştırmaya katılan tüketicilerin \%44,8'inin lise mezunu ve \%30,7'sinin ise üniversite mezunu olduğu belirlenmiştir. Tüketicilerin \%26,0's1 memurlardan, \%29,9'u ev hanımlarından ve \%21,4'ü de işçilerden oluşmaktadır. Tüketicilerin gelir durumları incelendiğinde, 3001-6000 TL arası gelire sahip olanların oranı \%52,6 olarak gerçekleşmiştir (Tablo1).

Tablo1.Tüketicilerin sosyo-ekonomik özellikleri $(\mathrm{n}=384)$

Table1. Socio-economic characteristics of consumers

\begin{tabular}{llccllll}
\hline Özellikler & & Say1 & $\%$ & Özellikler & & Say1 & $\%$ \\
\hline Cinsiyet & Erkek & 154 & 40,1 & Eğitim & İlköğretim & 54 & 14,1 \\
& Kadın & 230 & 59,9 & düzeyi & Lise & 172 & 44,8 \\
Yaş grupları & $18-30$ & 92 & 24,0 & & Yüksekokul & 40 & 10,4 \\
& $31-40$ & 128 & 33,3 & & Üniversite & 118 & 30,7 \\
& $41-50$ & 107 & 27,9 & Meslek & Memur & 100 & 26,0 \\
& $51-60$ & 50 & 13,0 & grupları & İşçi & 82 & 21,4 \\
Aile büyüklüğ̈̈ü & $61 \geq$ & 7 & 1,8 & & Ev hanımı & 115 & 29,9 \\
& $1-2$ & 65 & 16,9 & & Serbest meslek & 67 & 17,4 \\
& $3-4$ & 219 & 57,0 & & Emekli & 20 & 5,3 \\
& $4+$ & 100 & 26,0 & Gelir & 2000 TL ve altı & 34 & 8,9 \\
& & & & grupları & 2001-3000 TL & 91 & 23,7 \\
& & & & & $3001-6000 \mathrm{TL}$ & 202 & 52,6 \\
& & & & & 6001 TL $\geq$ & 57 & 14,8 \\
\hline
\end{tabular}

\section{Tüketicilerin süt ve süt ürünleri tüketimi ve tüketici bilinci}

Tüketicilerin süt ve süt ürünleri tüketimi konusunda bilinç düzeylerini belirlemek amaciyla süt ve süt ürünleri hangi besin ögelerini içerir sorusu yöneltilmiştir. Bu soruya, tüketicilerin \%64,3'ü bütün besin ögelerini içerir cevabını, \%26,6'sı protein kaynağıdır, $\% 6,5$ 'i vitamin ve mineral kaynağıdır, \%2,6'sı ise enerji kaynağıdır cevabını vermiştir. Tüketicilere süt ve süt ürünleri tüketim tercihinizde sizi teşvik eden ve bilinçlendiren en 
önemli bilgi kaynakları nelerdir sorusu yöneltilmiştir. Tüketicilerin \%89,3'ü televizyon ve sosyal medya cevabını vermiştir. Gazete ve dergi cevabını veren tüketici oranı $\% 9,1$ ve seminerler cevabını verenlerin oranı ise \%1,3 olarak gerçekleşmiştir. Günümüzde özellikle gençler arasında sosyal medya kullanımı ve tüm yaş gruplarını içeren bireylerde televizyon izleme oranının çok yüksek olması tüketicinin bilinçlenmesi açısından öncelikli araçlardır.

\section{Tüketicilerin Süt ve Süt Ürünleri Satın Alma Davranışları}

Araştırmada, tüketiciler eğitim durumlarına göre ilköğretim, lise, yüksekokul ve üniversite mezunu olmak üzere 4 gruba ayrılmıştır. Eğitim durumuna göre süt tüketiminde en çok hangi tüketim şeklini benimsedikleri sorulmuştur. Süt tüketimi, ilköğretim mezunlarında $\% 75,9$ oranında açık, \%7,4 oranında pastörize ve $\% 16,7$ oranında ise paket süt olarak tüketilmektedir. Üniversite mezunlarında ise \%41,5 oranında açık, \%20,3 oranında pastörize ve $\% 38,1$ oranında ise paket süt tüketildiği ortaya konulmuştur. Tüm yaş gruplarında açık süt tüketimi pastörize ve paket süt tüketiminden daha yüksek bulunmuştur. Tüm tüketici yaş grupları dikkate alındığında, \%62,0 oranında açık, \%12,0 oranında pastörize ve \%26,0 oranında ise paket süt tüketildiği belirlenmiştir. Çelik ve ark.(2005), Şanlıurfa ilinde yapmış oldukları çalışmalarında, satın alınan sütün \%46,3'ünün açık ve \%53,7'sinin ise ambalajlı süt olduğunu tespit etmişlerdir. Açık süt tüketim oranı, mevcut araştırmada, Çelik ve ark.(2005)'te bildirilen orandan daha yüksek düzeyde gerçekleşmiştir. Erzincan ilinde yapılan bir çalışmada, satın alınan sütün \%69,9'u sokak sütçülerinden ve $\% 30,1$ 'i ise marketlerden pastörize olarak satın alınmaktadır (Çebi ve ark., 2018). Sokak sütü tercih edilme oranının daha yüksek olması, mevcut araştırma sonuçları ile benzerlik göstermektedir. Tüketicilerin süt tüketim tercihleri ile eğitim durumları arasındaki farklılık istatistiki olarak anlamlı bulunmuştur $(\chi 2$ : 34.896; $\mathrm{p}=0,00<0,05)$. Tüketicilerin süt alırken açık sütü tercih etmelerinin nedenleri; fiyatın daha uygun olması (\%57,3), sütün süt olarak tüketilmesinin yanında yoğurt yapımında kullanılması $(\% 20,1)$, sütlü tatlı yapımında kullanılması $(\% 10,4)$ ve daha faydalı olduğu düşüncesidir (\%12,2), (Tablo 2). Erzincan ilinde yapılan bir çalışmada ailelerin açık süt tercih etme sebepleri; beğeni ve alışkanlıklardan $(\% 24,8)$, daha kolay temin edilmesinden $(\% 22,3)$, daha ekonomik olmasından (\%19,8) kaynaklanmaktadır (Erdal ve Tokgöz, 2011). Çalışma sonuçları ile çalışmamız sonuçları kısmen benzerlik göstermektedir.

Tablo 2. Tüketicilerin eğitim durumlarına göre süt tüketim tercihi $(\mathrm{n}=384)$

Table 2.Milk consumption preference according to educational status of consumers

\begin{tabular}{llcccc}
\hline Eğitim Düzeyi & & Açık süt & Pastörize süt & Paket süt & Toplam \\
\hline İlköğretim & Say1 & 41 & 4 & 9 & 54 \\
& $\%$ & 75,9 & 7,4 & 16,7 & 100,0 \\
Lise & Say1 & 125 & 13 & 34 & 172 \\
& $\%$ & 72,7 & 7,6 & 19,8 & 100,0 \\
Yüksekokul & Say1 & 23 & 5 & 12 & 40 \\
& $\%$ & 57,5 & 12,5 & 30,0 & 100,0 \\
Üniversite & Say1 & 49 & 24 & 45 & 118 \\
& $\%$ & 41,5 & 20,3 & 38,1 & 100,0 \\
Toplam & Say1 & 238 & 46 & 100 & 384 \\
& $\%$ & 62,0 & 12,0 & 26,0 & 100,0 \\
\hline
\end{tabular}

$\chi 2: 34.896 ; \mathrm{p}=0,00<0,05$ önemli 
Tüketicilerin süt ve süt ürünleri satın aldıkları yerler incelendiğinde, ürünlerin çoğunlukla küçük ölçekli marketlerden, süper marketlerden ve süt ve süt ürünleri işletmelerinden ve üreticilerden satın alındığı belirlenmiştir. Cinsiyete göre yapılan incelemede, erkek tüketicilerin \%38,3'ü marketleri tercih ederken, \%61,7'si süt ve süt ürünü satan işletmeler ile üreticileri tercih etmektedir. Kadın tüketicilerin 88'i marketleri ve 142'si ise süt ve süt ürünü satan işletmeler (mandıra) ile üreticileri tercih etmektedir. Tüketicilerin cinsiyetleri ile süt ve süt ürünleri satın alma yerleri arasında istatistiki açıdan anlamlı bir farkl11ık bulunmamaktadır $(\chi 2: 0,000 ; p=0,992>0,05)$ (Tablo 3). Bu çalışmada, tüketicilerin daha çok süt ve süt ürünleri satan işletmeler ile üreticileri tercih etmelerinin sebebi olarak, fiyatların daha uygun olması ve halkın Hatay iline özgü yöresel süt ürünlerini (tuzlu yoğurt, çökelek, künefelik peynir) daha çok tüketmelerinden kaynaklandığg ifade edilebilir. Erdal ve Tokgöz, 2011 yılında Erzincan ilinde yapmış oldukları çalışmada, tüketicilerin açık sütü $\% 60,8$ oranında kapıya gelen sütçülerden satın aldıklarını, \%5,8'i bakkallardan ve semt pazarlarından aldıklarını ve \%1,2'si ise kendi üretimleri olduğunu belirtmişlerdir. Tüketiciler ambalajlı sütü ise süper marketlerden ve mahalle bakkallarından satın almaktadır. Şanlıurfa'da yapılan bir çalışmada, ailelerin \%61,4'ü ambalajlı sütü süpermarketlerden \%21,1'i bakkallardan, \%17,5'i küçük marketlerden satın alırken; açık sütü \%33,7 oranında sokak sütçülerinden, $\% 27,0$ oranında bakkallardan, $\% 15,7$ oranında küçük ölçekli marketlerden satın aldıklarını ve \%7,9'unun ise kendilerinin üretimleri olduğu belirtilmiştir (Çelik ve ark., 2005).

Tablo 3.Tüketicilerin cinsiyetlerine göre süt ve süt ürünleri satın alma yerleri $(\mathrm{n}=384)$

Table 3. Milk and dairy purchasing places according to gender of consumers

\begin{tabular}{clccc}
\hline \multicolumn{1}{c}{ Cinsiyet } & $\begin{array}{c}\text { Market/Süper } \\
\text { market }\end{array}$ & $\begin{array}{c}\text { Süt ve süt ürünleri işletmeleri / } \\
\text { Üretici }\end{array}$ & Toplam \\
\hline Erkek & Sayı & 59 & 95 & 154 \\
& $\%$ & 38,3 & 61,7 & 100,0 \\
\multirow{4}{*}{ Kadın } & Sayı & 88 & 142 & 230 \\
& $\%$ & 38,3 & 61,7 & 100,0 \\
\multirow{5}{*}{ Toplam } & Sayı & 147 & 237 & 384 \\
& $\%$ & 38,3 & 61,7 & 100,0 \\
\hline
\end{tabular}

$\chi 2: 0,0000 ; p=0,992>0,05$ önemsiz

Tüketicilerin yaş gruplarına göre süt ve süt ürünleri satın aldıkları yerler incelendiğinde, 30 yaş ve altı tüketici grubu haricinde diğer yaş gruplarında süt ve süt ürünleri satan işletmeler ile üreticiler daha çok tercih edilmiştir. Otuz yaş ve altı tüketicilerin \%58,7'si market ve süper marketleri, \%41,3'ü ise süt ve süt ürünleri satan işletmeleri/üreticileri tercih etmektedir. Süt ve süt ürünleri satan işletmeleri ve üreticilerden ürün almayı en çok tercih eden yaş grubu ise 51 yaş ve üzeri olarak belirlenmiştir $(\% 73,7)$. Genç olan tüketicilerin daha çok market ve süper marketleri, ileri yaştaki tüketicilerin ise daha çok süt ve süt ürünleri satan işletmeler ile üreticileri tercih ettikleri görülmektedir. $\mathrm{Bu}$ sonuçlardan tüketicilerin alışkanlıklarını terk etmelerinin kolay olmadığı sonucunu çıkarabiliriz. Tüketicilerin süt ve süt ürünü satın aldıkları yerler ile yaş grupları arasında istatistiki açıdan önemli bir farklılık bulunmaktadir $(\chi 2: 25.341 ; \mathrm{p}=0,00<0,05)$ (Tablo 4$)$. 
Tablo 4.Tüketicilerin yaş gruplarına göre süt ve süt ürünü satın alma yerleri $(\mathrm{n}=384)$

Table 4. Milk and dairy purchasing places according to age group of consumers

\begin{tabular}{llccc}
\hline \multicolumn{2}{c}{ Yaş Grubu } & $\begin{array}{c}\text { Market/Süper } \\
\text { market }\end{array}$ & $\begin{array}{c}\text { Süt ve süt ürünleri işletmeleri/ } \\
\text { Üretici }\end{array}$ & Toplam \\
\hline \multirow{2}{*}{30 yaş alt1 } & Sayı & 54 & 38 & 92 \\
& $\%$ & 58,7 & 41,3 & 100,0 \\
\multirow{4}{*}{$41-40$} & Sayı & 49 & 79 & 128 \\
& $\%$ & 38,3 & 61,7 & 100,0 \\
\multirow{3}{*}{$51-+$} & Say1 & 29 & 78 & 107 \\
& $\%$ & 27,1 & 72,9 & 100,0 \\
\multirow{3}{*}{ Toplam } & Sayı & 15 & 42 & 57 \\
& $\%$ & 26,3 & 73,7 & 100,0 \\
& Sayı & 147 & 237 & 384 \\
& $\%$ & 38,3 & 61,7 & 100,0 \\
\hline
\end{tabular}

$\chi 2: 25.341 ; \mathrm{p}=0,00<0,05$ önemli

Tüketicilerin süt ve süt ürünleri satın aldıkları yerler ile eğitim durumları arasındaki ilişki incelendiğinde, eğitim seviyesi yükseldikçe market ve süpermarketlerden satın alma oranı artış göstermiştir (Tablo 5).

Tablo 5.Tüketicilerin eğitim durumlarına göre süt ve süt ürünü satın alma yerleri $(\mathrm{n}=384)$

Table 5. Milk and dairy purchasing places according to education status of consumers

\begin{tabular}{llccc}
\hline \multicolumn{2}{c}{ Eğitim Düzeyi } & $\begin{array}{c}\text { Market/Süper } \\
\text { market }\end{array}$ & $\begin{array}{c}\text { Süt ve süt ürünleri işletmeleri / } \\
\text { Üretici }\end{array}$ & Toplam \\
\hline İlköğretim & Say1 & 13 & 41 & 54 \\
& $\%$ & 24,1 & 75,9 & 100,0 \\
Lise & Say1 & 49 & 123 & 172 \\
\multirow{2}{*}{ Ön lisans } & $\%$ & 28,5 & 71,5 & 100,0 \\
& Say1 & 22 & 18 & 40 \\
Lisans & $\%$ & 55,0 & 45,0 & 100,0 \\
& Say1 & 67 & 51 & 118 \\
Toplam & $\%$ & 56,8 & 43,2 & 100,0 \\
& Say1 & 147 & 237 & 384 \\
& $\%$ & 38,3 & 61,7 & 100,0 \\
\hline
\end{tabular}

$\chi 2: 29.449 ; p=0,00<0,05$ önemli

Süt ve süt ürünleri satın alma bakımından market ya da süpermarketleri tercih edenlerin büyük çoğunluğunu $(\% 56,8)$ üniversite mezunları iken, süt ve süt ürünleri satan işletmeler ile üreticileri tercih edenlerin büyük çoğunluğunu ise $(\% 75,9)$ ilköğretim mezunları oluşturmuştur. Tüketicilerin ürün satın alırken, marka, ambalaj, kalite gibi özelliklere çok dikkat ettikleri gözlenmiştir. Tüketicilerde oluşan bu bilinç üzerinde ürün tanıtım amacı ile yapılan çeşitli faaliyetler etkili olmaktadır (reklamlar, promosyonlu ürünler, indirimli satışlar ve tanıtımlar).Tüketicilerin ürün satın aldıkları yerler ile eğitim durumları arasında istatistiki olarak önemli bir farklılık bulunmuştur $(\chi 2: 29.449 ; p=0,00<0,05)$ (Tablo 5).

Tüketicilerin aylık gelirleri ile süt ve süt ürünü satın alma yerleri arasında ilişki olup, olmadığı ki-kare testi ile analiz edilmiştir. Tüketiciler gelir durumuna göre üç gruba ayrılmış 
olup, 3.000 TL ve daha düşük aylık gelire sahip olan tüketiciler süt ve süt ürünlerini daha çok süt ürünleri satan işletmelerinden ve üreticilerden satın almayı tercih etmiştir (\%68). Tüketicilerin ürün satın aldıkları yerler ile aylık gelirleri arasında istatistiki olarak önemli bir farklılık bulunmaktadır $(\chi 2: 14.569 ; \mathrm{p}=0,00<0,05)$. Tüketicilerde gelir düzeyinin arttıkça, market ya da süpermarketlerden ürün satın alma oranının da arttığ 1 gözlenmiştir. Ancak, tüm gelir gruplarında süt ve süt ürünleri satan işletmeler ile üreticilerden ürün satın alma oranı yüksek bulunmuştur (Tablo 6).

Tablo 6. Tüketicilerin aylık gelir durumuna göre süt ve süt ürünü satın alma yerleri $(\mathrm{n}=384)$

Table 6. Milk and dairy purchasing places according to monthly income of consumers

\begin{tabular}{lllccc}
\hline $\begin{array}{c}\text { Gelir } \\
\text { Grubu }\end{array}$ & \multicolumn{2}{c}{ Aylık Gelir (TL) } & $\begin{array}{c}\text { Market/Süper } \\
\text { market }\end{array}$ & $\begin{array}{c}\text { Süt ve süt ürünleri işletmeleri / } \\
\text { Üretici }\end{array}$ & Toplam \\
\hline I. & \multirow{2}{*}{3.000 ve alt1 } & Say1 & 40 & 85 & 125 \\
& & $\%$ & 32,0 & 68,0 & 100,0 \\
II. & \multirow{2}{*}{$3.001-5.000$} & Sayı & 73 & 114 & 187 \\
& & $\%$ & 39,0 & 61,0 & 100,0 \\
III. & \multirow{2}{*}{5.001 ve üzeri } & Say1 & 34 & 38 & 72 \\
\multirow{2}{*}{ Toplam } & & $\%$ & 47,2 & 52,8 & 100,0 \\
& & Say1 & 147 & 237 & 384 \\
& & $\%$ & 38,3 & 63,7 & 100,0 \\
\hline$\chi 2: 14.569 ; p=0,00<0,05$ önemli & & &
\end{tabular}

Tüketicilerde aylık gıda harcamaları arttıkça, süt ve süt ürünleri satın aldıkları yerler market ya da süpermarketler lehine artış göstermektedir. Tüm gelir grupları incelendiğinde, süt ve süt ürünleri satan işletmeler $\% 61,7$ oranında tercih edilirken, market ya da süpermarketler \%38,3 oranında tercih edilmektedir. Tüketicilerin aylık gıda harcamaları ve ürün satın alma yerleri arasındaki ilişki istatistiki bakımdan önemli bulunmuştur ( $\chi 2: 12,019$; $\mathrm{p}=0,00<0,05)($ Tablo 7).

Tablo 7.Tüketicilerin aylık gıda harcamalarına göre süt ve süt ürünü satın alma yerleri (n= 384)

Table 7. Milk and dairy purchasing places according to monthly food expenditures of consumers

\begin{tabular}{llccc}
\hline \multicolumn{2}{c}{ Gıda harcaması (TL) } & $\begin{array}{c}\text { Market/Süper } \\
\text { market }\end{array}$ & $\begin{array}{c}\text { Süt ve süt ürünleri işletmeleri / } \\
\text { Üretici }\end{array}$ & Toplam \\
\hline \multirow{2}{*}{1.000 ve alt1 } & Say1 & 23 & 37 & 60 \\
& $\%$ & 38,3 & 61,7 & 100,0 \\
\multirow{2}{*}{$1.001-2.000$} & Say1 & 86 & 153 & 239 \\
& $\%$ & 36,0 & 64,0 & 100,0 \\
\multirow{4}{*}{ Topl ve üzeri } & Say1 & 47 & 38 & 85 \\
& $\%$ & 55,3 & 44,7 & 100,0 \\
& Sayı & 147 & 237 & 384 \\
& $\%$ & 38,3 & 61,7 & 100,0 \\
\hline
\end{tabular}

$\chi 2: 12,019 ; \mathrm{p}=0,00<0,05$ önemli 


\section{Süt ve süt ürünleri tüketiminde tüketimi etkileyebilecek ürün özellikleri}

Tüketicilerin gelir gruplarına göre süt ve süt ürünlerini tüketirken nelere dikkat ettikleri ve bunların önem düzeyleri Likert Ölçeği ile analiz edilmiş ve Cronbach's Alpha katsayısı hesaplanarak, güvenilirlik analizi yapılmıştır (Erman, 2007). Bulunan Cronbach's alpha katsayısı anket sorularının güvenilir olduğunu ortaya koymuştur (0.650). İncelenen tüm gelir gruplarında hijyen şartlarının çok önemli olduğu belirlenmiştir. İkinci gelir grubunda hijyen şartları daha yüksek bir önem düzeyine sahip $(4,80)$ olup, bunu ürünün sağlıklı olması $(4,84)$, ürün fiyatı $(4,00)$, ürünün indirimli olması $(3,72)$, organik olması $(3,48)$, ürünlerin ambalajlı olması $(3,25)$, ürünlerin markası $(3,64)$ ve üründe promosyon $(2,25)$ izlemiştir. Ortalama değer ise 4.76 olarak hesaplanmıştır (Tablo 8). Samsun ilinde yapılan bir çalışmaya göre, tüketicilerin süt ve süt ürünleri tüketiminde değişime neden olabilecek tutum örneklerinden en önemlisi sağlıklı olduğu düşüncesi olarak belirlenmiş (4.67), ikinci sırada ise hijyen şartları gelmiştir (Gündüz ve ark.,2013). Tutum ifadelerinin önem düzeyi mevcut çalışmanın sonuçları ile benzerlik göstermektedir.

Tablo 8. Tüketicilerin gelir gruplarına göre ürün tüketiminde değişiklik yapma ile ilgili tutumlar1

Table 8. Attitudes concerned with changes in product consumption acording to income groups of consumers

\begin{tabular}{|c|c|c|c|c|}
\hline & \multicolumn{4}{|c|}{ Gelir Grupları } \\
\hline & I & II & III & Ortalama \\
\hline Hijyen şartları & 4,69 & 4,80 & 4,75 & 4,76 \\
\hline İndirimli olması & 3,63 & 3,80 & 3,67 & 3,72 \\
\hline Üründe promosyon olmas1 & 2,11 & 2,38 & 2,13 & 2,25 \\
\hline Organik olması & 3,31 & 3,47 & 3,59 & 3,48 \\
\hline Ambalaj1 & 3,01 & 3,29 & 3,33 & 3,25 \\
\hline Markası & 3,53 & 3,70 & 3,62 & 3,64 \\
\hline Fiyatı & 3,90 & 4,01 & 4,05 & 4,00 \\
\hline Sağlıklı olması & 4,82 & 4,86 & 4,83 & 4,84 \\
\hline Ölçek $\quad$ Önemli Değil & Az Önemli & Önemli & Oldukça Önemli & Çok önemli \\
\hline 1 & 2 & 3 & 4 & 5 \\
\hline Cronbach's alpha: 0.650 & & & & \\
\hline
\end{tabular}

Tüketicilerin gelir gruplarına göre ürün özelliklerine dikkat etme konusundaki tutumları Likert Ölçeği ile analiz edilmiştir. Tüketicilerin en çok dikkat ettikleri ürün özellikleri; son tüketim tarihi $(2,98)$, gıda standartları $(2,84)$, üründe katkı maddesi bulunması $(2,75)$, Tarım ve Sağlık Bakanlığı üretim izni $(2,70)$, üretim yeri $(2,54)$ ve besin değeridir $(1,97)$. Gelir gruplarının ürün özelliklerine dikkat etme tutumları incelendiğinde, en az önemi birinci gelir grubundaki tüketicilerin verdiği $(1,76)$ tespit edilmiştir (Tablo 9). Gündüz ve ark.(2013) yaptıkları çalışmada, son tüketim tarihini en önemli $(2,75)$, gıda standartlarını ise ikinci derecede önemli (2.26) bulmuşlardır. Bu bakımdan mevcut çalışma sonuçları ile benzerlik göstermektedir. 
Tablo 9. Tüketicilerin ürün özelliklerine dikkat etme tutum ifadeleri

Table 9. Attitude statement pay attention to product features of consumers

\begin{tabular}{lcccc}
\hline & \multicolumn{4}{c}{ Gelir Gruplar1 } \\
& I & II & III & Ortalama \\
\hline Ürünün gıda standardı & 2,76 & 2,86 & 2,85 & 2,84 \\
Üretim yeri & 2,43 & 2,54 & 2,59 & 2,54 \\
Bakanlıkların üretim izinleri & 2,68 & 2,71 & 2,70 & 2,70 \\
Katkı maddesi bulunma durumu & 2,69 & 2,78 & 2,74 & 2,75 \\
Besin değeri içeriği & 1,76 & 2,01 & 2,02 & 1,97 \\
Son tüketim tarihi & 2,96 & 2,98 & 2,98 & 2,98 \\
Ölçek: $\quad$ Hiç Dikkat Etmem & \multicolumn{1}{c}{ Bazen dikkat ederim } & Dikkat ederim & \\
\multicolumn{4}{c}{3} \\
Cronbach's alpha: 0,668 & 2 & \multicolumn{4}{|c}{} \\
\hline
\end{tabular}

Yine tüketicilerin süt ve süt ürünleri tüketimini etkileyebilecek çevre faktörleri karşısında tüketici tutumları Likert ölçeği ile analiz edilmiştir. Tüketicilerin süt ve süt ürünleri tüketimini etkileyen çevre faktörleri; ailede küçük çocuk olması $(4,65)$, doktor tavsiyesi (4.35), aile bireylerinin süt içme arzusu $(2,64)$ ve eş-dost tarafindan yapılan tavsiyeler $(2,69)$ şeklinde sıralanmaktadır (Tablo 10).

Tablo 10.Tüketicilerin süt ve süt ürünleri tüketim miktarını etkileyebilecek çevre faktörleri Table 10. May affecting environmental factors the consumption of milk and dairy products of consumers

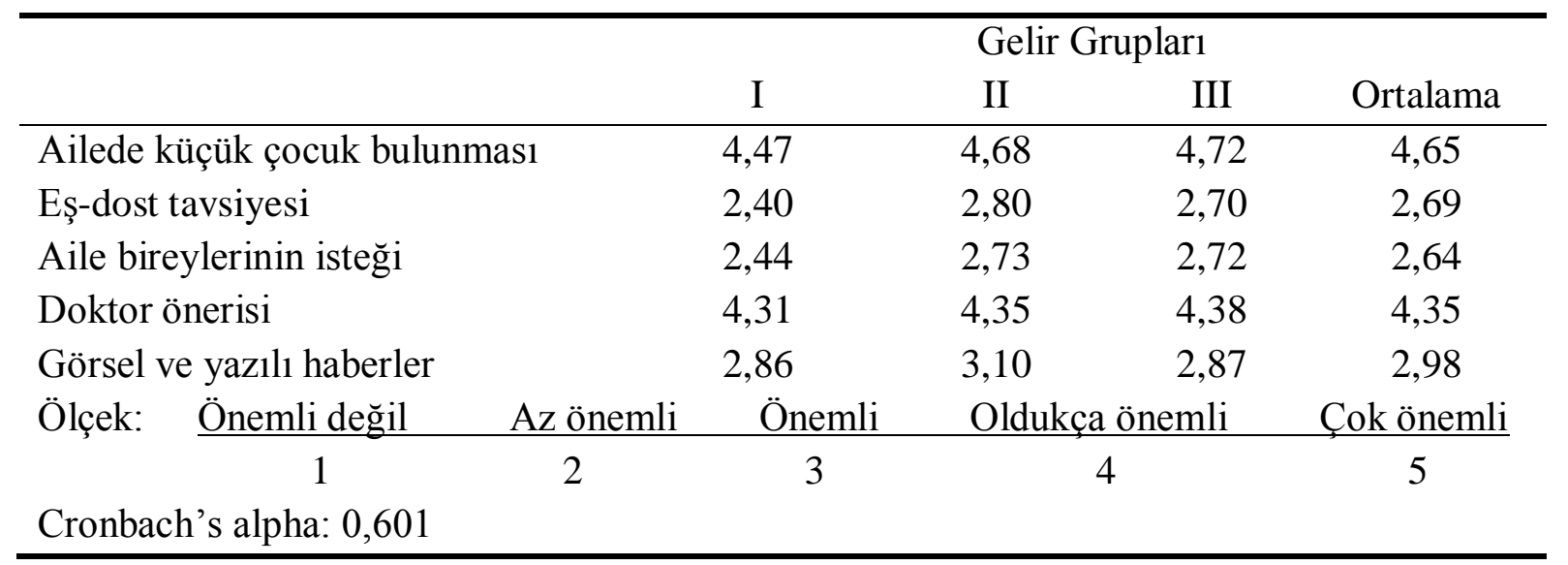

Tüketicilerin süt ve süt ürünleri satın alırken, marka tercihlerini etkileyen faktörler ise Çizelge 11'de verilmiştir. Tüketicilerden kaliteye en yüksek düzeyde önem verenler birinci derecedeki $(\% 88,5)$ olup, en düşük düzeyde önem verenler dördüncü derecedeki tüketicilerdir $(\% 0,5)$. Ucuzluğa en yüksek düzeyde önem verenler üçüncü derecedekiler $(\% 49,5)$ iken, en düşük düzeyde önem verenler birinci derecedeki $(\% 1,6)$ tüketicilerdir. Güvenilirliğe birinci derecede önem verenlerin oran $1 \% 8,9$, ambalaja birinci derecede öncelik verenlerin oranı ise $\% 1,6$ olarak gerçekleşmiştir. Marka tercihinde kalite birinci derecede $(\% 88,5)$, güvenilirlik ikinci derecede $(\% 66,7)$, ucuzluk üçüncü derecede $(\% 49,5)$, ambalaj ise dördüncü derecede $(\% 28,6)$ en çok tercih edilen faktörler olarak sıralanmıştır (Tablo 11). Mevcut araştırma 
sonuçları, Şanlıurfa ilinde kentsel alanda tüketicilerin süt tüketim düzeyleri ve süt tüketim alışkanlıkları konulu çalışma (Çelik ve ark, 2005) sonuçları ile benzerlik içerisindedir. Literatürde, tüketiciler kaliteyi birinci derecede öncelikli $(\% 71,6)$, güvenilirliği ikinci derecede öncelikli $(\% 53,5)$, ucuzluğu üçüncü derecede öncelikli ve ambalajı ise dördüncü derecede öncelikli olarak bulmuşlardır.

Tablo 11. Tüketicilerin süt ve süt ürünlerinde marka tercihinde öncelik durumu Table 11. Precedence status in brand preference for milk and dairy products

\begin{tabular}{lcccccccc}
\hline Faktörler & \multicolumn{7}{c}{ Tüketici Sayllar1 ve Oranlar1 } \\
& 1.derece & $\%$ & 2.derece & $\%$ & 3.derece & $\%$ & 4.derece & $\%$ \\
\hline Kalite & 340 & 88,5 & 39 & 10,2 & 3 & 0,8 & 2 & 0,5 \\
Ucuzluk & 6 & 1,6 & 73 & 19,0 & 190 & 49,5 & 115 & 29,9 \\
Güvenilirlik & 34 & 8,9 & 256 & 66,7 & 79 & 20,6 & 15 & 3,9 \\
Ambalaj & 6 & 1,6 & 16 & 4,2 & 110 & 28,6 & 252 & 65,6 \\
\hline
\end{tabular}

\section{Sonuç}

$\mathrm{Bu}$ çalışma ile tüketicilerin süt ve süt ürünleri kullanımındaki bilinç durumu, süt ve süt ürünleri satın alımındaki tercihleri, bazı demografik özelliklerine göre satın alma yerleri ve satın alma yerleri arasındaki ilişkilerin önem durumu, tüketicilerin süt ve süt ürünlerinin tüketimindeki tercihleri incelenmiştir. Tüketicilerin eğitim durumları ile süt tüketim tercihleri arasındaki ilişki önemli bulunmuştur. Tüketicilerin büyük çoğunluğu açık sütü tercih etmiştir. Araştırma sonuçlarına göre tüketicilerin süt ve süt ürünleri tüketiminde satın alma yerleri arasında erkek ve kadınlarda süt ve süt ürünleri işletmeleri ve üreticiler daha çok tercih edilen yerler olmuştur. Tüketicilerin yaş grupları ve süt ve süt ürünleri satın alma yerleri arasında önemli bir ilişki bulunmuş ve tüketicilerin yaşları arttıkça daha çok süt ve süt ürünü satan işletmeleri ve üreticileri tercih etmiştir. Otuz yaş ve altı tüketicilerin diğer yaş gruplarına göre daha yüksek oranda market ve süper marketleri tercih etmiştir. Bu tercihte en önemli faktörlerin gençlerin markaya ve kaliteye daha fazla önem vermeleri söylenebilir. İleri yaştaki tüketicilerin daha çok alışılmış olanı tercih ettikleri ve yöresel ürünleri terk edemedikleri görülmektedir. Eğitim seviyesi artışı ile birlikte market ve süper marketlerden ürün alımı da giderek artmaktadır. Tüketicilerin aylık gelir düzeyleri arttıkça, market ve süpermarketler lehine bir artış görülmektedir. Tüketicilerin gelir düzeyleri arttıkça, işlenmiş ürünlere olan talepte de artış gözlenmiştir. Tüketicilerin ürün değiştirme hakkında verecekleri kararlarda, ürünün sağlıklı olması, hijyen ve fiyatı en etkili faktörler olarak ön plana çıkmıştır. Aile içinde çocuk bulunması ve doktorun tavsiyesi gibi çevre faktörleri, tüketicilerin süt ve süt ürünleri tüketim miktarını etkileyen çevre faktörleri olarak bulunmuştur. Tüketicilerin süt ve süt ürünü tercih ederken birinci derecede kaliteye, ikinci derecede güvenilirliğe, üçüncü derecede ucuzluğa ve dördüncü derecede ise ambalaj durumuna önem verdikleri belirlenmiştir. Tüketicilerin süt ve süt ürünleri harcamalarının, toplam gıda harcamaları içindeki payı oldukça düşük gerçekleşmiştir. Araştırma sonuçları, özellikle tüketicilerde çocuk gelişimi için çok gerekli olan ve birçok vitamin ve besleyici maddeyi içinde bulunduran sütün tüketim bilincinin mutlaka geliştirilmesi gerektiğini, bu amaçla eğitim ve reklamın etkili 
olduğunu, özellikle süt ve süt ürünlerinde ambalaja önem verilmesi gerektiğini, ambalajlı ve kaliteli süt ve süt ürünleri üreten işletme sayısının artırılabilmesi için yatırımların özendirilmesi gerektiğini ortaya koymuştur.

\section{Kaynaklar}

Altunışık, R., Coşkun, R., Yıldırım, E., 2005. Sosyal Bilimlerde Araştırma Yöntemleri: SPSS Uygulamal1.(4.Bask1) Sakarya Kitabevi, Sakarya ,365s.

Anonim, 2017. Türkiye süt, et, gıda sanayicileri ve üreticileri birliği sektör raporu. http://www.setbir.org.tr/. Erişim tarihi: 19.06.2018

Collins, M., 1986. Sampling (Editör: R.worcester ve ark.1986), Consumer Market Research Handbook

Çebi, K., Özyürek, S., Türkyılmaz, D., 2018. Süt ve süt ürünleri tüketiminde tüketici tercihlerini etkileyen faktörler. YYÜ Tarım Bilimleri Dergisi. 28(1):70-77

Çelik, Y., Karlı, B., Bilgiç, A., Çelik, Ş., 2005.Şanlıurfa ili kentsel alanda tüketicilerin süt tüketim düzeyleri ve süt tüketim alışkanlıkları. Tarım Ekonomisi Dergisi. 11(1):5-12

Erdal, G., Tokgöz, K., 2011. Tüketicilerin ambalajlı ve açık süt tüketim tercihlerini etkileyen faktörler :Erzincan ili örneği. KMÜ Sosyal ve Ekonomik Araştırmalar Dergisi. 13(20):111-115

Erman, U.E., 2007. SPSS kullanma klavuzu, istatistik merkezi yayın no:1, http://yunus.hacettepe.edu.tr/ tonta/courses/spring2009/bby606/SPSS 15.0 ile Veri Analizi.pdf. Erişim tarihi 01.08.2020.

Gündüz, O., Kılıç, O., Emir, M., Aydın, G., 2013. Süt ve süt ürünleri tüketiminde tüketici tercihlerini etkileyen faktörler. Gida Teknolojileri Elektronik Dergisi. 8(1):36-43

Karakaya, E., Akbay, C., 2014. İstanbul ili kentsel alanda tüketicilerin açık ve paket süt tüketim alışkanlıkları. Tarım Ekonomisi Dergisi. 20 (1): 17-27

Kibar, M., Yılmaz, A., Mikail, N., 2020. Siirt ili merkez ilçede süt ve süt ürünleri tüketim alışkanlıkları ve etkileyen faktörler. Batman Üniversitesi Yaşam Bilimleri Dergisi. 10(1):99-113

Küçük,R.,2020. Hatay ilinde süt ve süt ürünleri üreten işletmelerin üretim, pazarlama yapısı ve ihracat durumu. Mustafa Kemal Üniversitesi Fen Bilimleri Enstitüsü, Tarım Ekonomisi Anabilim Dalı Yüksek Lisans tezi, $88 \mathrm{~s}$

Malhotra, N.K., 2004. Marketing research (AN applied orientation). Pearson Prentice Hill. Fourth Edition.

Niyaz, Ö. C.,İnan, İ.H., 2016. TR22 Güney marmara bölgesindeki tüketicilerin süt ve süt ürünleri tüketim düzeylerinin belirlenmesi. ÇOMÜ Ziraat Fakültesi Dergisi. 4(2):713

Özyürek, S., Yangılar, F., Çebi, K., 2019. Erzincan üniversitesi öğrencilerinin süt ve süt ürünleri tüketim alışkanlıklarının incelenmesi, Black Sea Journal of Agriculture. 2(3):119-125

Say Şahin, D., Saraç, Z.F., 2019. Burdur ilindeki 65 yaş ve üzeri tüketicilerin süt ve süt ürünleri tüketim alışkanlıkları. Bursa Uludağ Üniversitesi Ziraat Fakültesi Dergisi. 34(1):119-133 
Sevimli, L., Gülçubuk, B., 2018. Kırmızı et ve ürünlerinde tüketicilerin satın alma tercihlerinde etkili olan faktörler. Tarım Ekonomisi Araştırmaları Dergisi. 4(2):25-33

Tapkı, N., Demirtaş, B., Dağıstan, E., 2020. Hatay kent merkezindeki tüketicilerin zeytinyağı satın alma tercihlerini etkileyen faktörlerin belirlenmesi, Türk Tarım ve Doğa Bilimleri Dergisi. 7(2):331-341 